\title{
Fibras, plumas y colores del pueblo ishir. Identidad $y$ resistencia en el Chaco paraguayo
}

\section{Fibers, feathers and colours of the ishir people. Identity and endurance in the Chaco paraguayo}

\author{
Silvana Di Lorenzo ${ }^{1}$ y Silvia Manuale ${ }^{2}$ \\ ... Y asi fue como la guacamaya se agarró color y ahi lo anda paseando, por si a los \\ hombres y mujeres se les olvida que muchos son los colores y los pensamientos, y que el \\ mundo será alegre si todos los colores y todos los pensamientos tienen su lugar.
}

(S.I. Marcos 1999, p. 49).

\section{Resumen}

En este trabajo se describe un objeto singular del pueblo ishir conservado en el Museo Etnográfico Juan B. Ambrosetti de la Universidad de Buenos Aires. Se hace referencia al contexto histórico y sociocultural de origen, mencionando los antecedentes de investigación. Los estudios realizados con respecto a la manufactura y el significado del tocado de plumas ishir permiten dar cuenta de la complejidad técnica y de un determinado sentido estético y simbólico; y plantear, a través de su biografía, un recorrido histórico hasta la actualidad política de los pueblos originarios del Gran Chaco.

Palabras claves: tocado, originarios, manufactura, aves, shaman.

\begin{abstract}
The present work describes a singular object of the ishir people conserved in the Ethnographic Museum Juan B. Ambrosetti of the University of Buenos Aires. It makes reference to the original historical and sociocultural context, mentioning the research background. The investigations performed with regard to manufacture and significance of the ishir feather headdress enable us to account for the technical complexity and particular aesthetic and symbolic meaning; and propose a historical overview to the current political situation of the original native societies of the Gran Chaco.
\end{abstract}

Keywords: headdress, original, people, manufacture, birds, shaman.

Recibido: 8 junio 2016. Aceptado: 24 noviembre 2016

1 Museo Etnográfico Juan B. Ambrosetti, Facultad de Filosofía y Letras, Universidad de Buenos Aires, Moreno 350, CP1091, Buenos Aires, ARGENTINA. Email: sildilor@hotmail.com.

2 Museo Etnográfico Juan B. Ambrosetti, Facultad de Filosofía y Letras, Universidad de Buenos Aires, Moreno 350, CP1091, Buenos Aires, ARGENTINA. Email: silmanuale@gmail.com. 


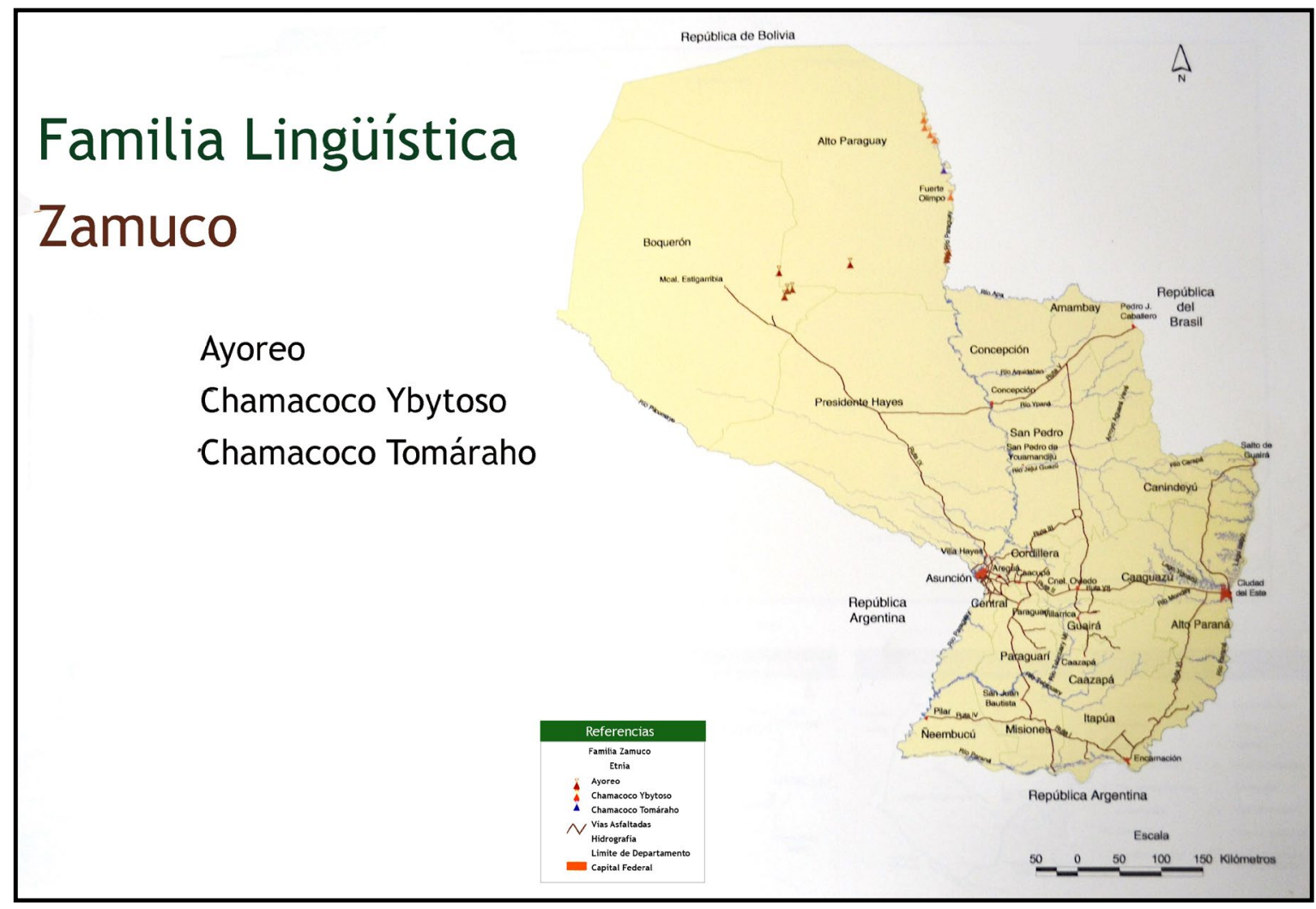

Figura 1. Mapa actual con la distribución de los pueblos originarios del Alto Paraguay. Fuente: Atlas de las comunidades indígenas en el Paraguay. Dirección General de Estadísticas, Encuestas y Censos (DGEEC).

\section{Introducción}

La población ishir habita la región noreste del $\mathrm{Pa}$ raguay, y se ubica desde Bahía Negra hasta Puerto La Esperanza, ex puerto Sastre (Figura 1). Antiguamente denominados chamacoco, a sí mismos se llaman ishir, término que no solo hace referencia a la noción de persona sino que también abarca todo el conjunto de individuos que comparten esa cultura. $\mathrm{Al}$ igual que los ayoreo, pertenecen a la familia lingüística de los zamuco (Cordeu, 1980).

Dos grupos étnicos se diferencian en este pueblo: los ebytoso ${ }^{3}$, que son los pobladores más cercanos a las riberas del río Paraguay, y los tomáraho, quienes ocupan la región del Puerto de María Elena, Pitian-

3 Diferentes autores hablan de Ebydoso (Cordeu, 1980), Ybytóso (Sequera, 2006), para denominar al mismo grupo étnico. En este texto nosotras decidimos utilizar la acepción según Escobar (1999). tuta (Dirección General de Estadística, Encuestas y Censos [DGEEC], 2004).

A principios de la década de 1900, el pueblo ishir se encontraba en un proceso de desestructuración sociocultural en un contexto nacional de avance efectivo sobre los territorios de las comunidades originarias (Cordeu, 1980). Con el justificativo de emprendimientos económicos que harían de Paraguay una nación moderna, y frente a un medioambiente rico en recursos naturales diversos, el gobierno nacional permitió que una empresa extranjera (Carlos Casado S.A.) que se había instalado ya a fines del siglo XIX en la región, continuara apropiándose del territorio, y que los mismos habitantes originarios fueran utilizados como mano de obra casi esclava ${ }^{4}$ para el desmonte (Sequera, 2006).

4 A partir de los relatos publicados por Sequera (2006, pp. 61-62), se interpreta que las condiciones de trabajo en la empresa Carlos Casado S.A. pueden clasificarse 
Hacia 1912 ingresaba al Museo Etnográfico de la Universidad de Buenos Aires un conjunto de objetos que había pertenecido a ese pueblo despojado de su territorio. Entre ellos, se destacaba un tocado de plumas, por su belleza, complejidad en la manufactura y buen estado de conservación, el cual quedaría almacenado por más de un siglo en una institución científica y académica para ser contemplado, estudiado y resignificado, y que es considerado hoy como parte del arte plumario ishir.

$\mathrm{El}$ arte plumario de esta sociedad originaria lo mismo que la pintura corporal han sido estudiados por varios autores, quienes han señalado su sentido estético y, a la vez, su carácter mítico-religioso (Cordeu, 1986; Escobar, 1999, 2012; Spadafora, 2006).

Retratos fotográficos de los primeros viajeros, descripciones, recopilación de los mitos y rituales, estudios comparativos de los objetos recolectados en los trabajos de campo, la revisión bibliográfica y el estudio de la técnica plumaria permiten contextualizar, revalorizar y resignificar el tocado de plumas conservado actualmente en el Museo Etnográfico de Buenos Aires. Así, el relevamiento de los retratos realizados por los viajeros y otros investigadores de campo más la información recogida en diferentes fuentes contemporáneas, nos permiten poner en valor un objeto coleccionado y considerado como exótico en el pasado a la vez que relacionarlo con un contexto actual de reclamos identitarios.

\section{Breves líneas de un pueblo visitado}

Hacia fines del siglo XIX y principios del XX, dos exploradores europeos, Guido Boggiani, fotógrafo y artista plástico, y Alberto Vojtech Frîc, botánico; ambos interesados en la recolección de datos etnográficos y objetos culturales de pueblos nativos de Sudamérica, dejaron las primeras impresiones del pueblo ishir en imágenes, palabras escritas y en donaciones de piezas en varios museos del mundo. Otros trabajos como los de Baldus y Belaieff ofre-

como mano de obra casi esclava en el sentido de la forma de pago, que muchas veces consistía solo en víveres y alcohol, a lo que se suman 12 horas diarias de trabajo y las condiciones insalubres de trabajo que provocaron muchas muertes. cieron los primeros registros lingüísticos y de características físicas del ambiente chaqueño, respectivamente. Luego de la Guerra del Chaco, la etnógrafa eslovena Branislava Susnik vivirá largas estadías entre los ishir, realizando principalmente estudios lingüísticos y registrando los cambios ocurridos a partir del trabajo de los indígenas en el obraje. ${ }^{5}$

\section{La biografía de un tocado de plumas ishir}

Victoria Aguirre, quien había nacido a mediados del siglo XIX, pariente del artista plástico Prilidiano Pueyrredón, descendiente de los Anchorena e integrante de la Sociedad de Beneficencia, dedicó parte de su vida a comprar, coleccionar y donar objetos culturales a diversas instituciones públicas, muchas veces haciendo efectivo este hecho de forma anónima. Esta coleccionista apoyó económicamente a varios artistas y colaboró con las expediciones científicas llevadas a cabo por el Museo de La Plata (Pegoraro 2009).

Entre los objetos etnográficos donados por Victoria Aguirre al Museo Ambrosetti existe un conjunto procedente del pueblo ishir, que comprende una bolsa de cuero, dos bolsas de caraguatá, un cinturón de caraguatá y algodón con cuentas de vidrio ${ }^{6}$, dos pipas de cerámica y tres objetos plumarios: un par de muñequeras, un collar y un tocado cefálico de plumas.

El tocado cefálico de plumas que tratamos en este trabajo (Figura 2) representa un objeto singular, recolectado con anterioridad a los cambios históricos y económicos que produjo la Guerra del Chaco en la década de $1930 .^{7}$ Catalogado con el simple nombre de "adorno de plumas" en el antiguo libro de

5 En un trabajo anterior (Di Lorenzo et al., 2015) hemos revisado más detalladamente los primeros antecedentes acerca de los ishir, percatándonos de que existe una extensa bibliografía para ser consultada: Baldus (1927); Belaieff (1941); Boggiani (1900); Cordeu (1980, 1984); Kandert (1983); Pegoraro (2009); Richard (2008); Sequera (2002); Susnik (1957); Trevisan (1980).

6 Este objeto fue catalogado en su ingreso al Museo como "vincha".

7 Ver Richard (2008) en referencia a los cambios acaecidos luego de la Guerra del Chaco (1932-1935). 


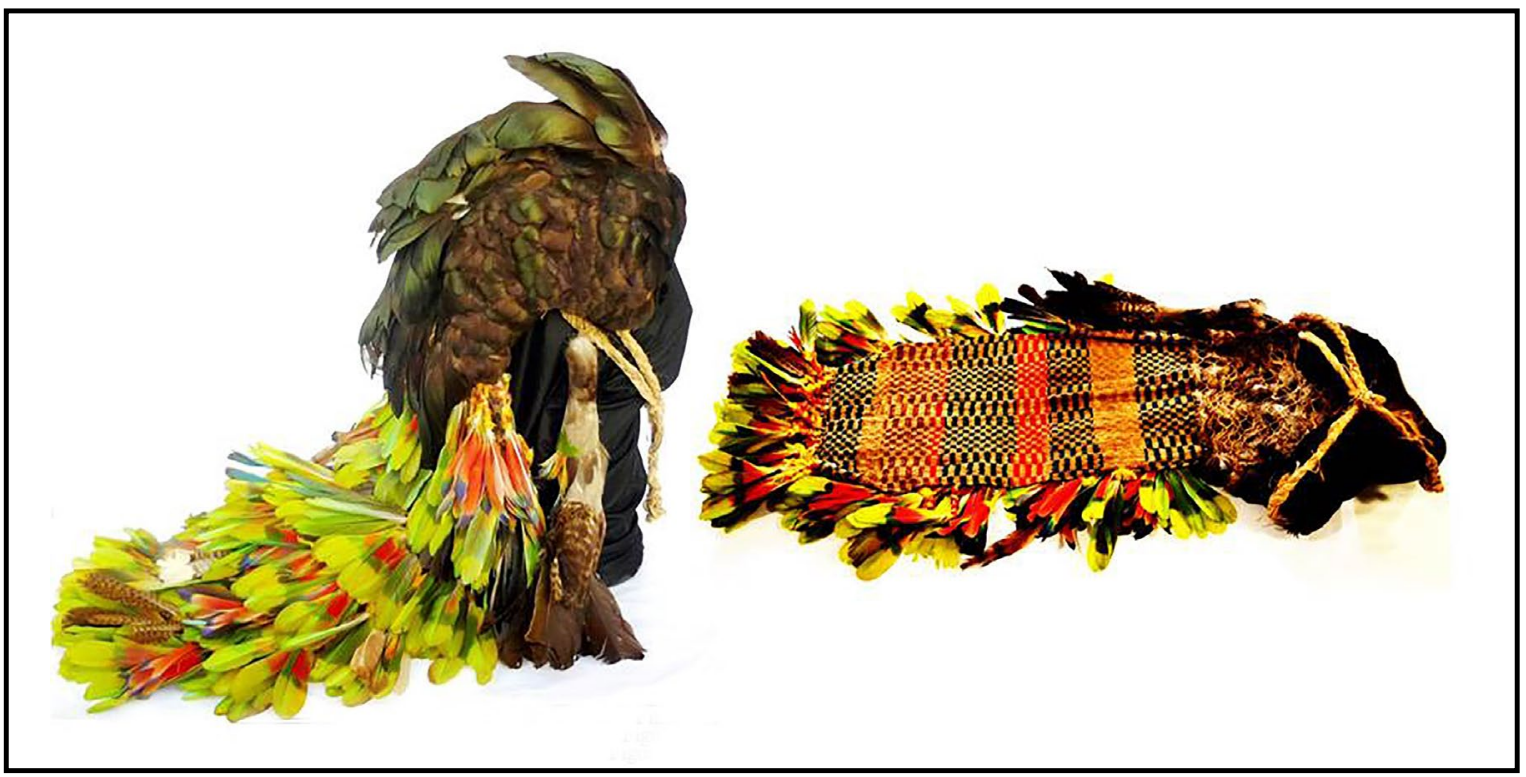

Figura 2. Tocado de plumas ishir $\mathrm{N}^{\circ} 11074$ (anverso y reverso).

ingreso de las colecciones al Museo, esta pieza etnográfica constituye, sin embargo, un único y complejo adorno o tocado cefálico de plumas.

\section{Sobre la técnica del tocado y los materiales preferidos para su manufactura}

El tocado de plumas fue registrado con el número de inventario 11074 y está compuesto de dos partes. En una representación esquemática, visto del reverso, se podría describir mediante un círculo de 260 $\mathrm{mm}$ de diámetro y un rectángulo de $520 \mathrm{~mm}$ x 265 $\mathrm{mm}$, para el gorro y el cubrenuca, respectivamente (Figura 3).

Así, la parte superior del tocado, con forma de gorro elástico está realizada con la técnica de hilera de plumas (Figura 4) sobre un cordel base con enlaces de nudo simple (Ribeiro 1957). Se plantea la hipótesis de que una sola hilera de plumas va enlazándose, y junto a otros cordeles subsidiarios van formando un tipo de red (Figura 5). Los cordeles utilizados terminan en ambos lados del gorro y se sujetan de forma trenzada (Figura 6). ${ }^{8}$

8 Por motivos de conservación del objeto, no se hizo una



Figura 3. Esquema del tocado $\mathrm{N}^{\circ} 11074$ formado por un gorro y un cubrenuca unidos por una costura. Dibujo realizado por Silvia Manuale. 

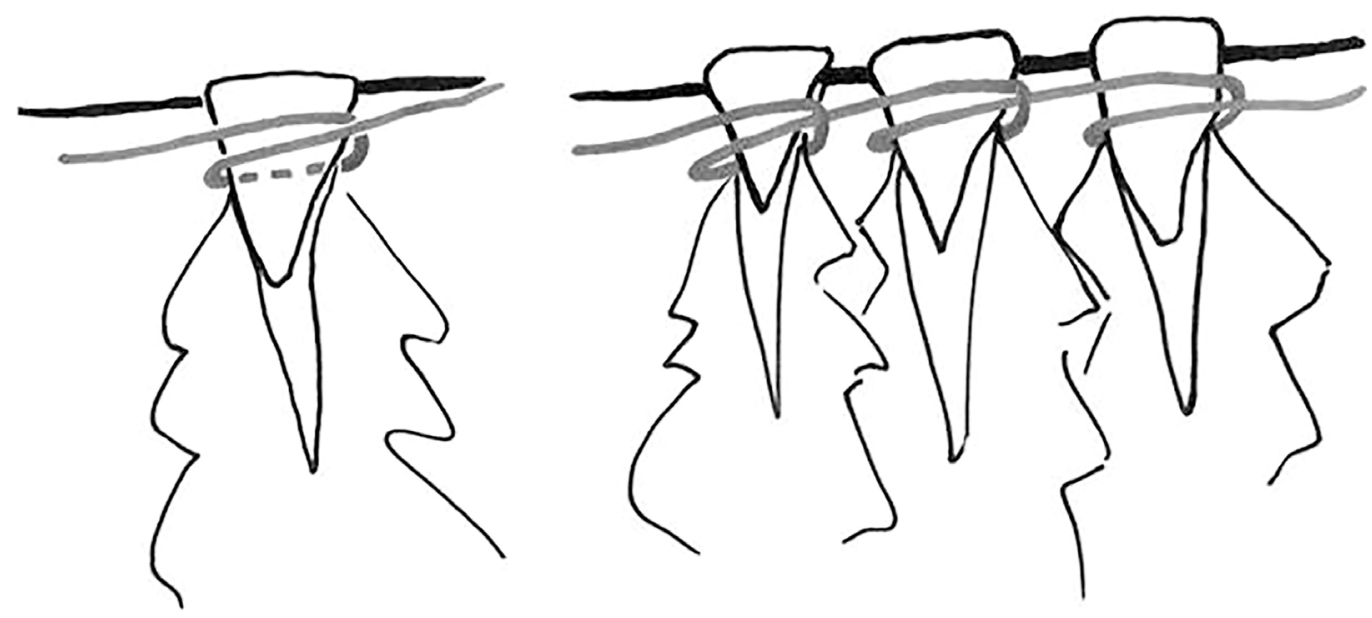

Figura 4. Técnica de hilera de plumas. Dibujo realizado por Silvia Manuale.

La parte inferior del tocado se trata de un cubrenuca tejido (Figura 7) con la técnica de malla, enlace interconectado, figura de ocho (Di Lorenzo et al., 2015; Seiler Baldinger, 1994). La unión del cubrenuca al gorro se realiza mediante una costura simple con puntadas equidistantes (Figura 8) y es posible observar que este hilo de unión también va enlazando y sujetando las hileras de plumas del gorro (Figura 9). En el anverso de la malla del cubrenuca se insertan hileras de fustes ${ }^{9}$ o manojos de plumas; para este tipo de accesorio se plantea una técnica similar a la de las varas emplumadas (Di Lorenzo et al., 2015), con la diferencia de que el soporte o alma donde se insertan las plumas pequeñas es un cordón en vez de una vara de madera; de esta forma, varios plumones se van amarrando a un cordel que se enrolla en forma imbricada algunas veces, y otras, en forma de roseta (Ribeiro, 1988) sobre un cordón doble en cuyo extremo se amarran plumas medianas

manipulación lo suficientemente exhaustiva que permitiera abrir los hilos y las plumas y corroborar fehacientemente la técnica empleada; en consecuencia dejamos planteada la técnica como hipotética.

9 En el Catálogo del Museo del Barro (2008), Escobar clasifica como fustes un tipo de manojo de plumas que son utilizados como accesorios pendientes y están elaborados con la técnica de enrollado de hilera de plumas sobre un cordón doble. por medio del doblez de su cálamo; siete hileras de estos manojos de plumas son colocadas mediante costura, en forma transversal al tejido del cubrenuca (Figura 10). Un fuste plumario de aproximadamente $35 \mathrm{~cm}$ de largo se ata en un lado, como pendiente, a la altura de la oreja del personaje.

La fibra vegetal utilizada en todo el tocado es la del caraguatá, un tipo de bromeliácea que se encuentra en todo el territorio del Gran Chaco. Mientras que los hilos que forman el gorro no están teñidos, los presentes en el cubrenuca combinan hilos no teñidos con aquellos teñidos en colores azul, marrones y rojo, en una disposición geométrica de cuadrados y rectángulos.

Las plumas elegidas para este tocado proceden de aves de la región y pertenecen al menos a seis especies diferentes según lo identificado hasta el momento (Di Lorenzo et al., 2015).

La parte superior del tocado está compuesta por una gran cantidad de plumas caudales, remeras y plumones de aves adultas marrones oscuras con tonos iridiscentes verdes de pato bragado o pato criollo (Cairina moschata). Posiblemente las plumas blancas ubicadas en el cubrenuca pertenezcan a las alas de esta ave acuática. 




Figura 5. Enlace de las hileras de plumas que forman el gorro. Dibujo realizado por Silvia Manuale.

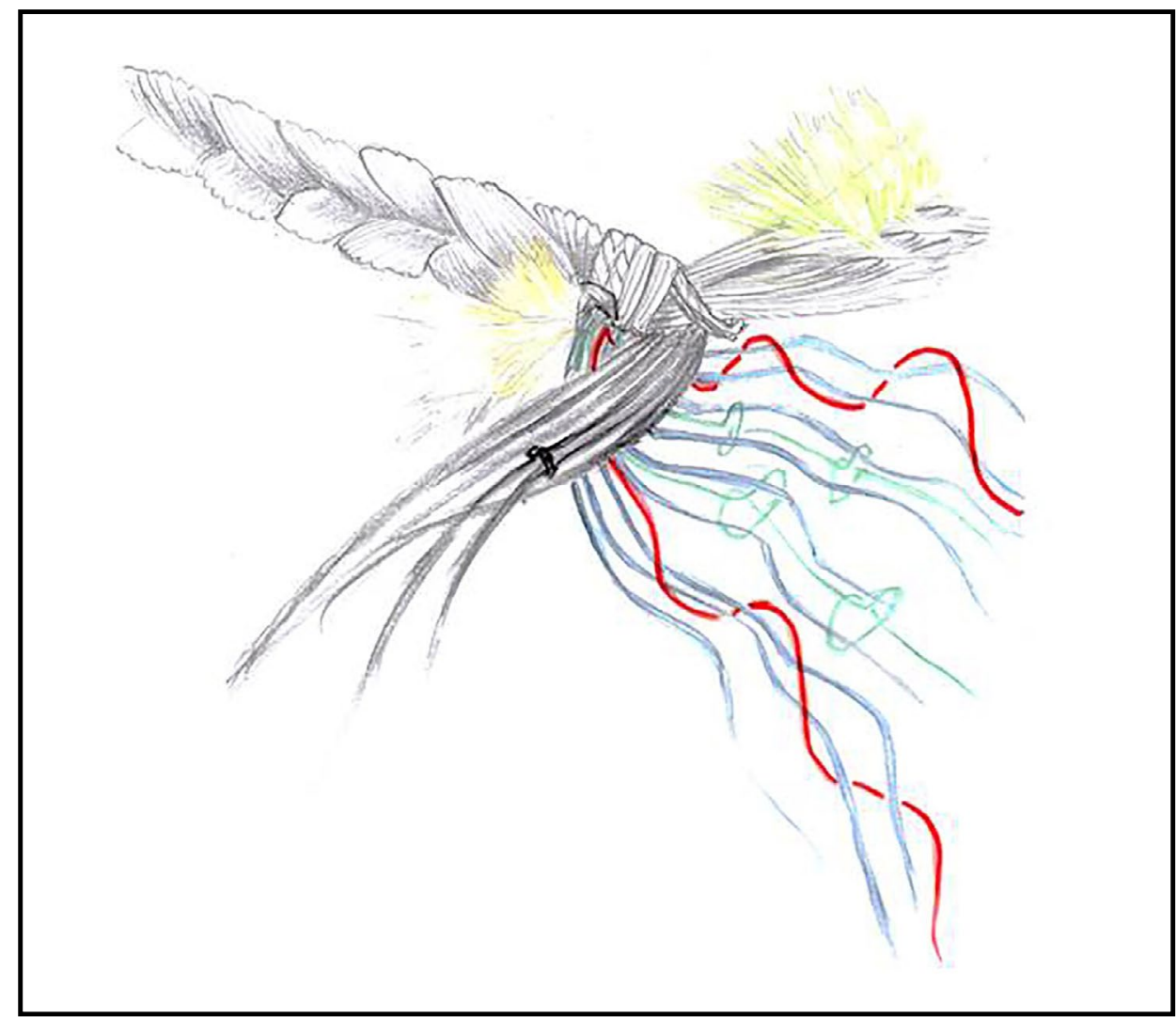

Figura 6. Terminaciones en trenzados de las hileras de pluma del gorro del tocado. Dibujo realizado por Silvia Manuale. 


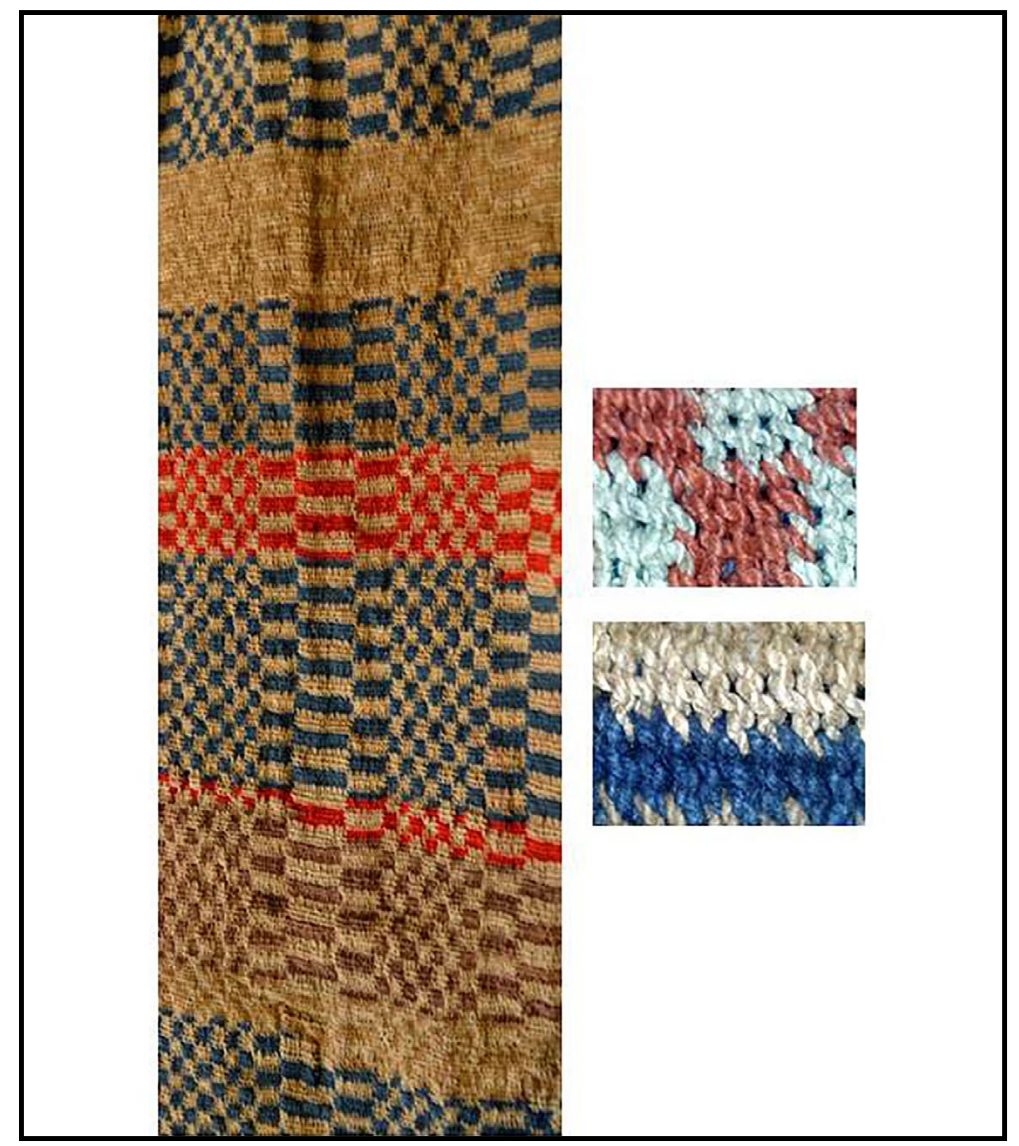

Figura 7. Técnica de malla, enlace interconectado.

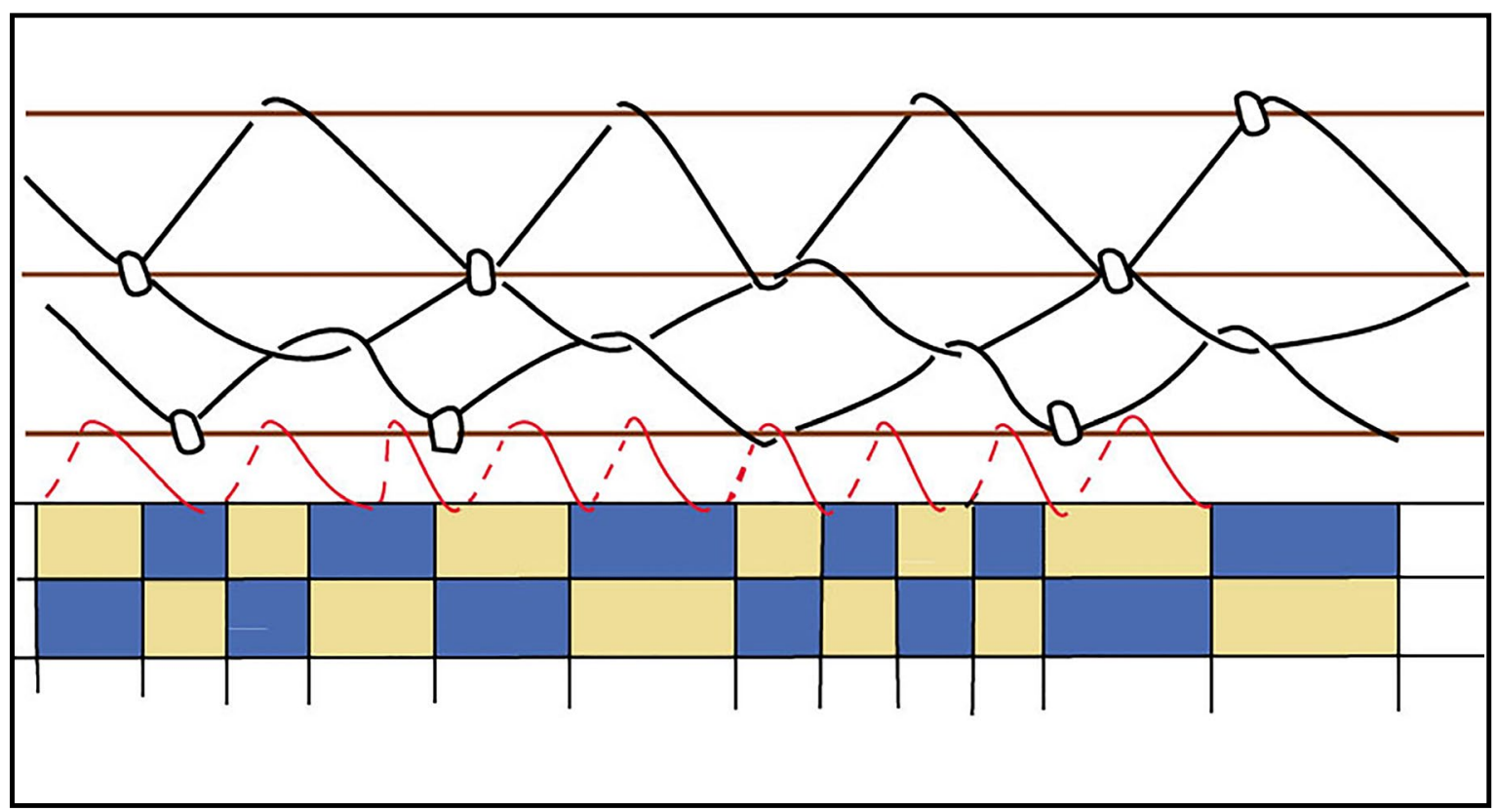

Figura 8. Costura de la unión del gorro con el cubrenuca. Dibujo realizado por Silvia Manuale. 


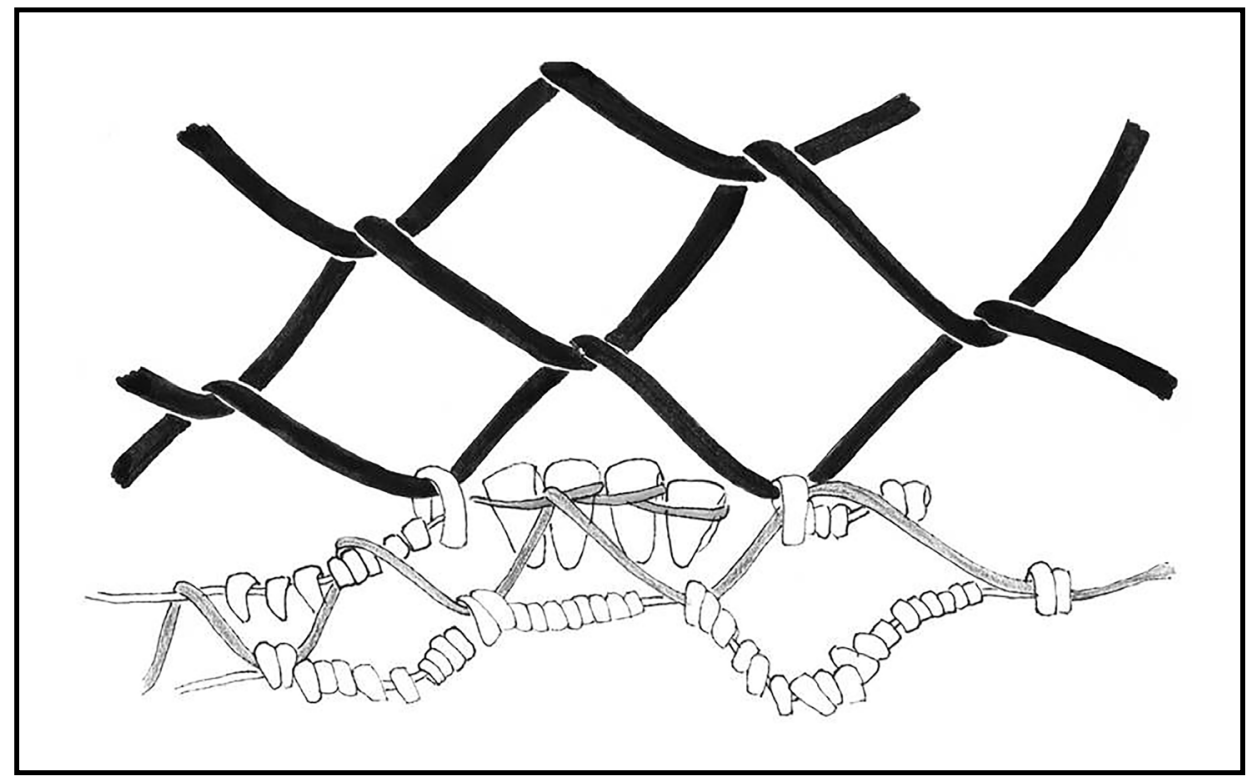

Figura 9. Enlaces de hileras de plumas entre gorro y cubrenuca. Dibujo realizado por Silvia Manuale.

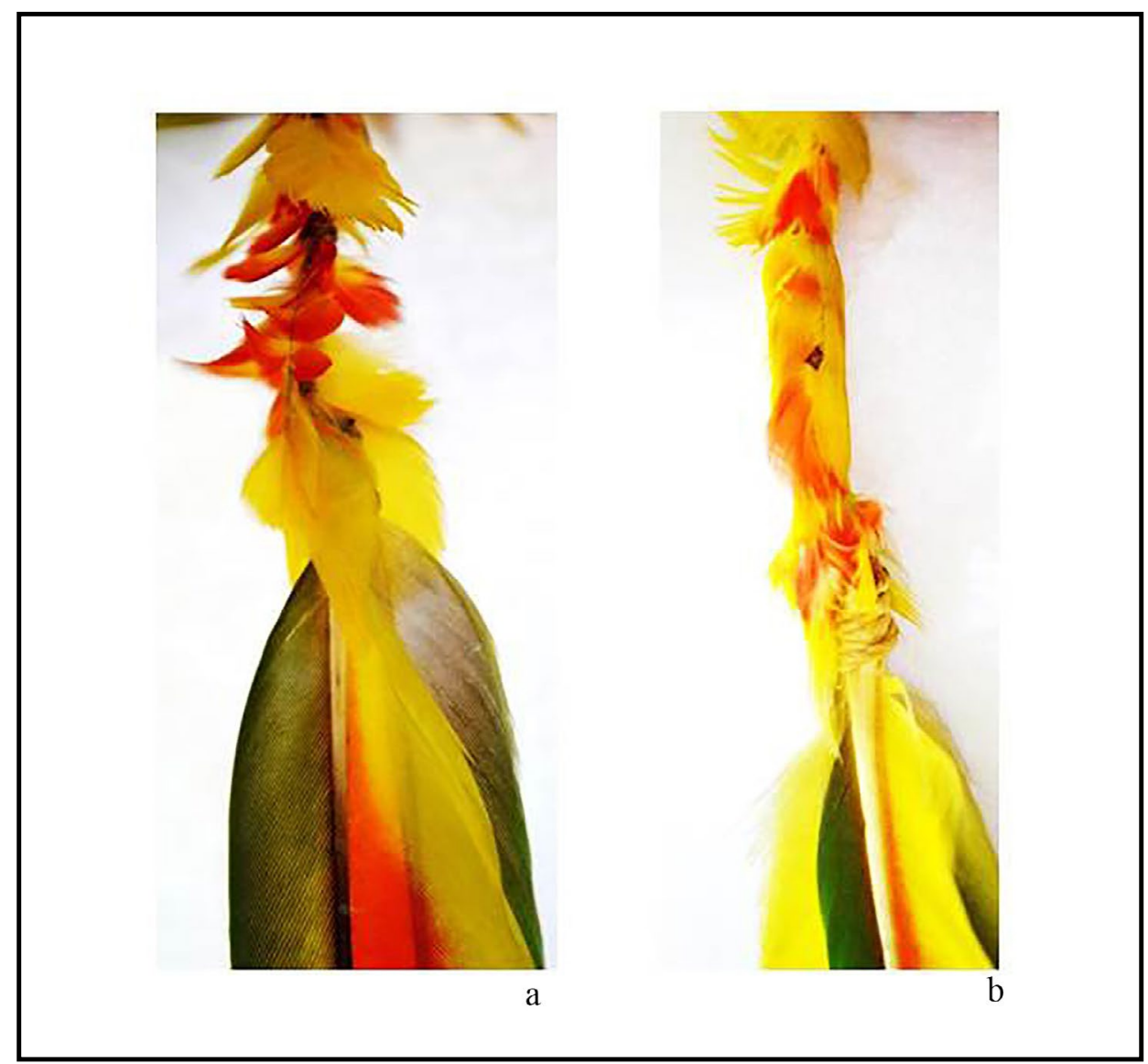

Figura 10. Fustes amarrados en el cubrenuca con la técnica de emplumado en roseta y la técnica de emplumado imbricada. 
La parte inferior o cubrenuca está formada por una mayor variedad de especies de aves, aunque predominan las plumas verdes, rojas, amarillas y azules del loro hablador (Amazona aestiva). Al igual que en el gorro, también se han utilizado plumas del ala, de la cola y plumones del ave en diferentes partes del cubrenuca. Las plumas marrones provienen de una especie de pava de monte, denominada charata (Ortalis canicollis), junto con plumas grises de paloma (Columbidae) y marrones con pintas o líneas que podrían pertenecer a rapaces diurnas como el halcón reidor (Herpetotheres cachinnans). Una pluma que sobresale por su color y forma es la que pertenece al burgo (Momotus momota); se trata de un ave selvática de un color azul intenso, de la que se han utilizado las plumas largas de la cola (D. Olivera, com. pers. 2015), la cual termina en dos timoneras y presenta un raquis parcialmente sin plumas (Narosky e Yzurieta, 2006).

Aún quedan especies por determinar, ya que algunas plumas presentan dudas, como aquellas que exhiben un diseño más variado y que combinan colores claros y oscuros. ${ }^{10}$

\section{Aves y hombres revestidos de plumas}

Las plumas cumplen varias funciones en un ave. Dan protección a la piel, proporcionan aislación, cumplen requisitos fundamentales para la aerodinámica. En algunas especies, las aves utilizan sus plumas para cumplir funciones determinadas como producir sonido o transportar agua para sus pichones (Brooke y Birkhead, 1991).

En el ámbito cultural de los ishir, el uso de los accesorios plumarios por parte de los shamanes obedece a razones "terapéuticas", "mágico-propiciatorias", “ceremoniales” y “extáticas” (Escobar, 1999, p. 129).

Aves y hombres comparten así cualidades de protección y de vuelo, y una apariencia externa que los hace diferenciarse, a las aves en su especie y a los hombres en sus roles especiales.

$10 \mathrm{Al}$ momento de escribir este artículo aún no se producía la visita al Museo Argentino de Ciencias Naturales para la consulta de las especies embalsamadas con el objetivo de usarlas como material comparativo para la identificación de las especies dudosas del tocado ishir.
Planteamos que la manufactura del gorro del tocado que analizamos presenta una apariencia similar a la de un ave acuática y que esto posiblemente fuera intencional. En este sentido, existen registros como los del antropólogo Cordeu, quien en 1984 entrevistó al cacique Bruno Barras acerca de este tocado. Denominado en ishir axnyrt wogoro o komzaxo wogoro ${ }^{11}$, dicho cacique atribuyó este tocado a los shamanes del agua, concediendo significado a la pieza según las especies de aves empleadas en su confección (Cordeu, 1986).

Esa apariencia del gorro comparable con la de un pato se logra mediante una magnífica complejidad técnica visualizada en la manipulación de un objeto tan frágil como es la pluma; así el hombre ishir elaboró un gorro colocando pluma por pluma en hileras continuas de hilos, observables por el reverso del objeto, pero que en su apariencia anversa, es decir, desde la visión ornamental de las plumas, aparenta que hubiera colocado el ave entera.

Escobar describió y utilizó nombres originarios para dar cuenta de la función que cumplen los tocados cefálicos con plumas de pato:

Los tomáraho llaman lepper wolo, así como los ebytoso, manon wolo, a un característico tocado de plumas negras de pato que tiene por base una redecilla de caraguatá y que, una vez colocado sobre la cabeza, se confunde con el pelo oscuro y espeso de sus portadores, a quienes otorga una apariencia fantástica. Sobre la frente se levanta, arisco, un copete de plumas más largas, siempre negras y provistas de reflejos metálicos; sugiere el enojo del pato macho que queda erizado y tembloroso, dicen los ishir... estos cascos de alto copete son, sobre todo, piezas chamánicas por excelencia. En la ceremonia de los chamanes llamada Shu Deich (La Derrota del Sol) durante la cual los konsaha cantan durante un día entero, ellos usan los lepper wolo para ahuyentar el sueńo y recobrar fuerzas. Estos gorros también sirven para regular fenómenos meteorológicos: las plumas del

11 Shaman-gorro. 
pato se asocian tanto al aire como al agua. El lepper wolo tiene una versión más reducida llamada manahna hijá (literalmente, "pecho del pato"12), que es usada por los novicios, los wetern, luego de que hayan portado el nymagarak, la guirnalda roja. Hoy, ambos tocados son prácticamente iguales, puesto que los lepper wolo han perdido los largos cubre nucas que los distinguían del gorro de los iniciados... Según los grados de su poder chamánico, los konsaha incluían en los copiosos plumajes que cubrían sus espaldas colores de aves diferentes. Entre los ebytoso se emplea el orn ohür, gran cubre nuca confeccionado sobre una base de red de caraguatá densamente cubierta de plumas, por lo general de lechuza, garza blanca, espátula, loro, pato o urraca. Sobre esta pieza que dilata y eriza la espalda dando a su portador el aspecto de una enorme ave de plumas desplegadas, se añaden, según las circunstancias, las diademas, guirnaldas, varillas emplumadas y ceñidores... Los chamanes lo utilizan para rechazar las enfermedades infecciosas (Escobar, 2012, pp. 206, 208).

Entre los objetos plumarios mencionados por Cordeu con respecto al uso ceremonial, hace referencia al manó woló o manoxno woló, caracterizando así al "casquete de plumas negras de pato con una prominencia en el extremo; las plumas van entramadas de manera muy cerrada a una malla de bromelia" (Cordeu, 1999, p. 77). Además de señalar la existencia de significados aún no totalmente descifrados según la especie y los colores de las aves, este autor también se refiere a parte de la técnica empleada en la confección de los tocados plumarios (Cordeu, 1999).

$\mathrm{El}$ arte plumario es denominado por los ishiro $k a-$ cha werzta y considerado como algo otorgado por la deidad Aishnuwéhrta que representaría su poder, transferido a los ishiro ${ }^{13}$ (Ozuna s.f.). En una recopilación de relatos ancestrales junto a imágenes que revelan a los shamanes ataviados con plumas es posi-

12 Comillas en el original.

13 Plural de ishir. ble leer en lengua nativa y en español las historias sobre shamanes y así saber que "siempre hubo grandes shamanes para prevenir y curar las enfermedades. Los shamanes sueñan y por los sueños son sanadores. Tienen que sońar el espíritu de cualquier ser de los que tienen mucho poder para adquirir el poder para curar"14 (Ozuna, s.f., p. 37).

\section{El hombre ishir revelado en imágenes antiguas $y$ contemporáneas}

Existe un abundante registro fotográfico de hombres ishir con sus vestimentas y accesorios emplumados.

Guido Boggiani legó varias imágenes de hombres y mujeres ishir, las cuales fueron comercializadas en formato de postales y además publicadas con interés científico en 1904. Según Reyero (2012), estas fotografías, muchas de las cuales muestran a los ishiro posando y sonriendo evidencian un sentido estético diferente al del pueblo indígena: donde el artista europeo ve belleza, el originario ishir vería peligro. Posiblemente este acercamiento tan estrecho e inconsulto habría provocado ciertas reacciones en la comunidad originaria muy alejadas de las intenciones del italiano, que incluso podrían tener que ver con el destino fatal de Boggiani. ${ }^{15}$ Imágenes reveladas que habrían expuesto cuestiones secretas de la sociedad ishir serían las causales del asesinato del fotógrafo y el enterramiento de sus materiales fotográficos (Reyero 2012).

Las largas estadías del checo Alberto V. Frîc entre los ishiro, su forma de involucrarse con la comunidad y su concreto accionar en la denuncia política en congresos internacionales ${ }^{16} \mathrm{y}$ en la recuperación de territorio in-

14 "Dos grandes shamanes. Dios del cielo y el dios de la tierra III" (Ozuna, s.f.).

15 Boggiani fue asesinado en territorio ishir en extrañas circunstancias. Al respecto, Reyero (2012) menciona una cita de Frîc (1904) publicada por Richard (2006, p. 38): "Cerca de una colina había una cueva y ahí le han asesinado [...]. Tenían miedo de las medicinas así que las habían enterrado. Debido a los poderes mágicos de Boggiani había muerto ya mucha gente".

16 En el Congreso Internacional de Americanistas realizado en 1908 en la ciudad de Viena, Frîc denunció el maltrato al que eran sometidos los indígenas del Brasil 


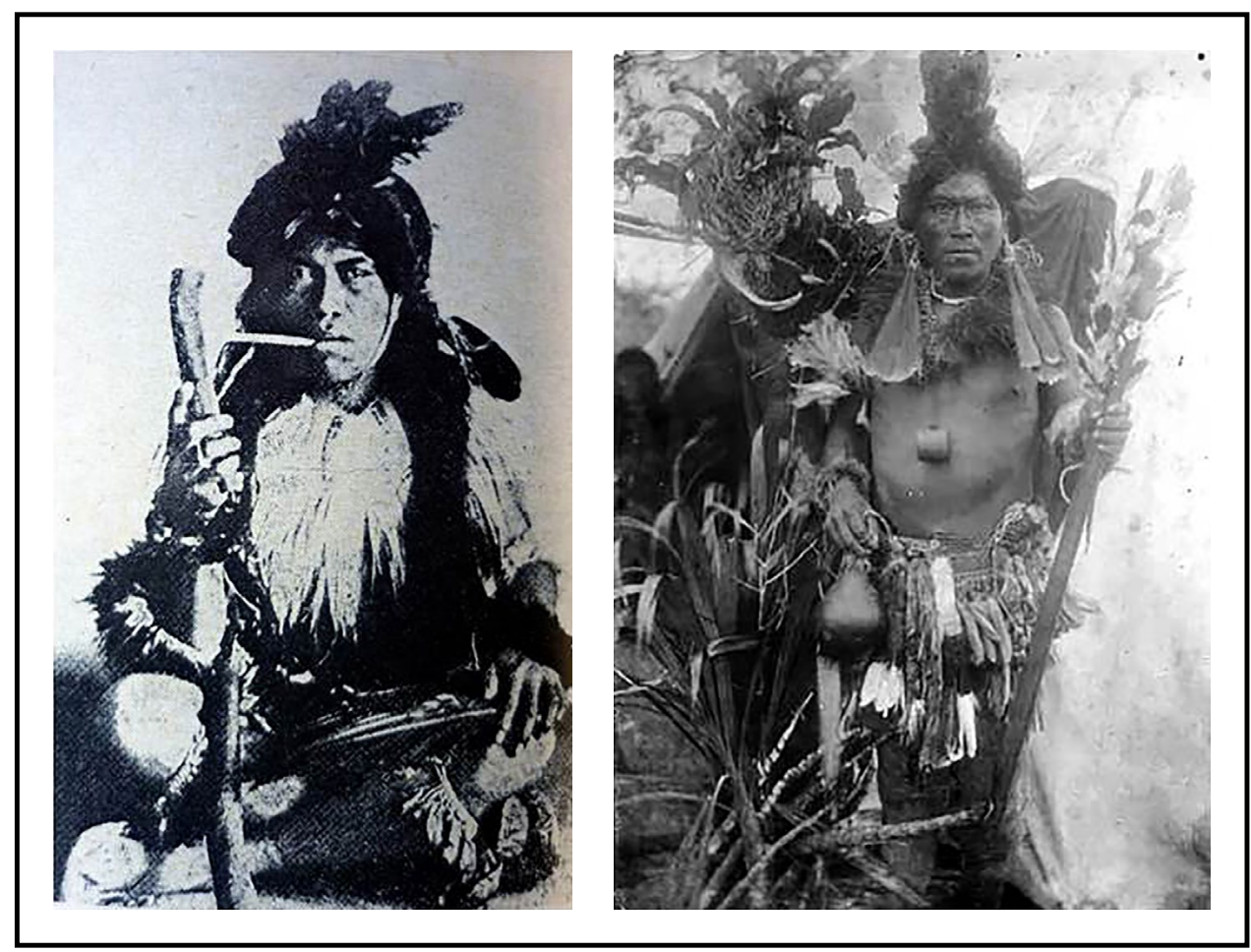

Figura 11. Fotografías de hombres ishir tomadas por Frîc.

Fuentes: Kandert (1983) y http://www.checomacoco.cz/chamacoco/image

dígena se conjugaron con la recopilación de términos originarios para la organización de un vocabulario indígena, la recolección de objetos culturales, un registro escrito y una documentación fotográfica exhaustiva, existiendo más de mil negativos que no fueron publicados en el archivo en Praga (Trevisan 1979).

En 1908, luego del tercer viaje al Chaco paraguayo, Frîc regresó a Praga con Chervuish, un hombre ishir que vestía su tocado de plumas (Figura 11) y quien había viajado miles de kilómetros para encontrar una cura a una enfermedad que padecía junto a muchos integrantes de su pueblo (Kandert 1983).

Entre los estudiosos europeos que recorrieron el Chaco Boreal, se encuentra el zoólogo Hans Krieg, cuyas fotografías realizadas en 1931 registran el uso de tocados con plumas de pato "moschusente", es decir, de la especie Cairina moschata (Figura 12). Como resultado de la expedición alemana al Gran

no solo por las autoridades del gobierno, sino por los extranjeros que formaron colonias en territorio originario (Pegoraro 2009).
Chaco, Krieg publicó una serie de fotos de hombres ishir de frente y de perfil, totalmente ataviados con diferentes accesorios plumarios y mostrando sus peinados. Del mismo modo reveló la desnudez de las mujeres y la de los nińos jugando en el territorio (Krieg, 1934).

En fechas más recientes y como parte de los datos recolectados por Escobar y Sequera en la década de 1980 en sus viajes al territorio ishir con el "interés de conocer una cultura inquietante y movidos enseguida por el afán de apoyar sus demandas de tierras propias y libertad de culto" (Escobar, 1999, p. 9), es posible contar con un amplio registro de ceremonias en forma de imágenes y relatos míticos. Wylky, shaman tomáraho, fue fotografiado por Ticio Escobar en 1987; junto a su sonaja y su cinturón de plumas verdes y rojas de loro hablador, lucía su tocado de plumas oscuras con reflejos verdes de pato (Figura 13).

Actualmente, Andrés Ozuna, ishir ebytoso, se ha referido al tocado de plumas como manahna hijá, cuya traducción es piel de pato; y nos comunica (Figura 14) 


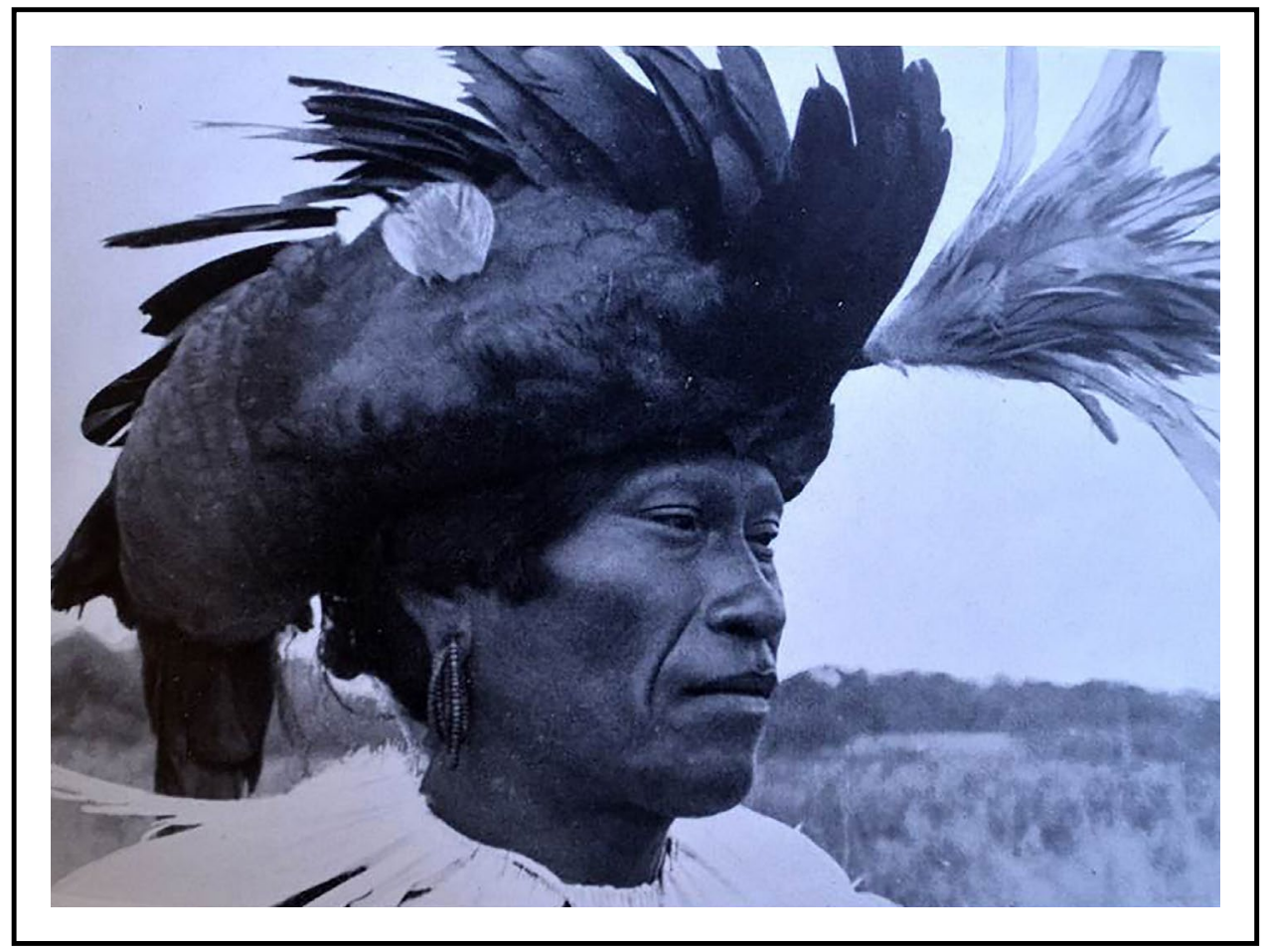

Figura 12. Foto de hombre ishir. Fuente: Krieg (1934).

que casi ya no existen estos tocados en su comunidad, ya que los shamanes, hacedores de sus propios atuendos están muriendo y todas sus pertenencias quedan con ellos ${ }^{17}$ (Di Lorenzo et al., 2015).

\section{Colores y seńales en el cuerpo}

Los ishiro recurren a una gama de colores determinada para la expresión de sus símbolos y su actuación en las ceremonias.

$\mathrm{El}$ arte corporal manifestado a través de figuras de manos, líneas, puntos, chorreaduras o superficies enteras, pintadas generalmente en tres colores básicos como el negro, el rojo y el blanco, contrasta con el colorido más amplio de los accesorios plumarios que adornan y significan también el cuerpo ishir.

17 En 2013 tuvimos el gusto de conocer a Andrés Ozuna gracias al contacto de Adelina Pusineri del Museo Etnográfico Andrés Barbero de Asunción, Paraguay. En esa ocasión Andrés nos brindó su conocimiento originario que nos ayudó a contextualizar el patrimonio ishir existente en nuestro museo.

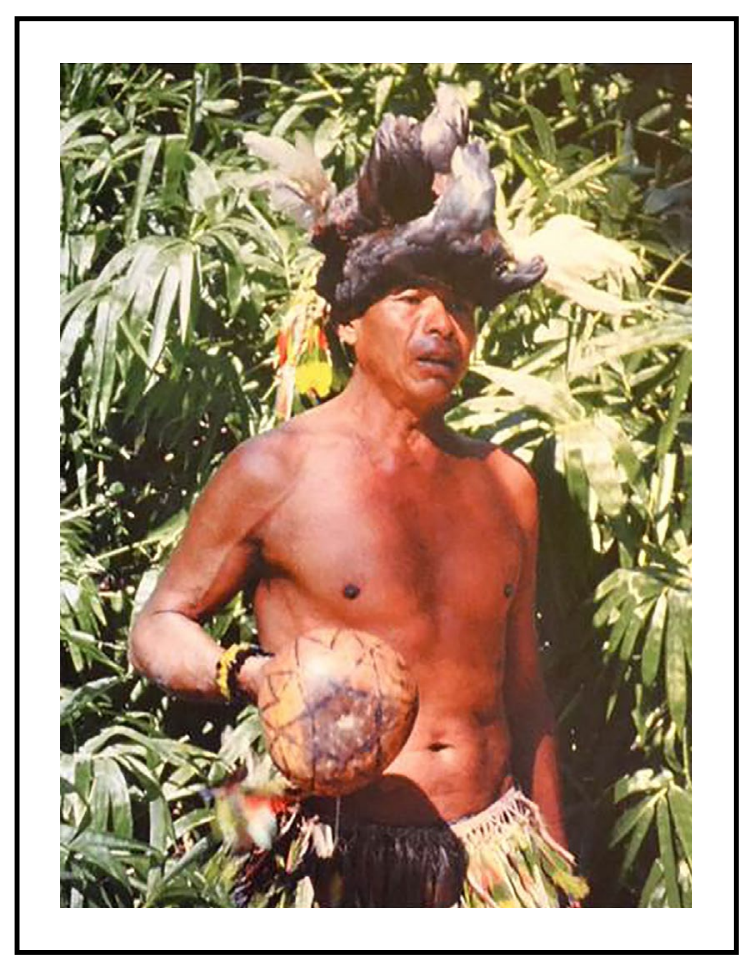

Figura 13. Foto tomada por Ticio Escobar al shaman tomáraho Wylky. Fuente: Catálogo Museo del Barro (2008). 


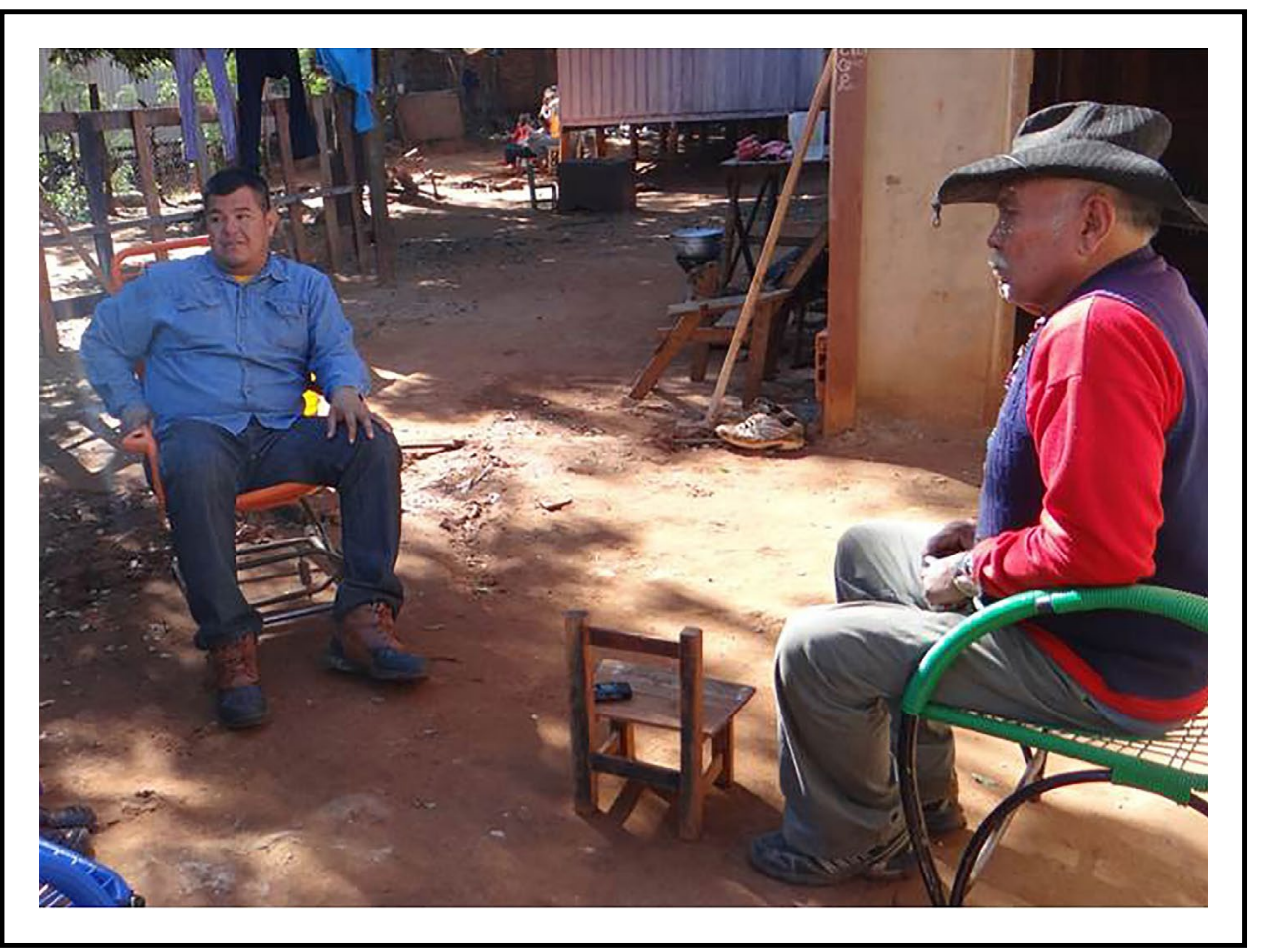

Figura 14. Andrés Ozuna y Clemente López en Luque. Foto tomada por Silvia Manuale (2013).

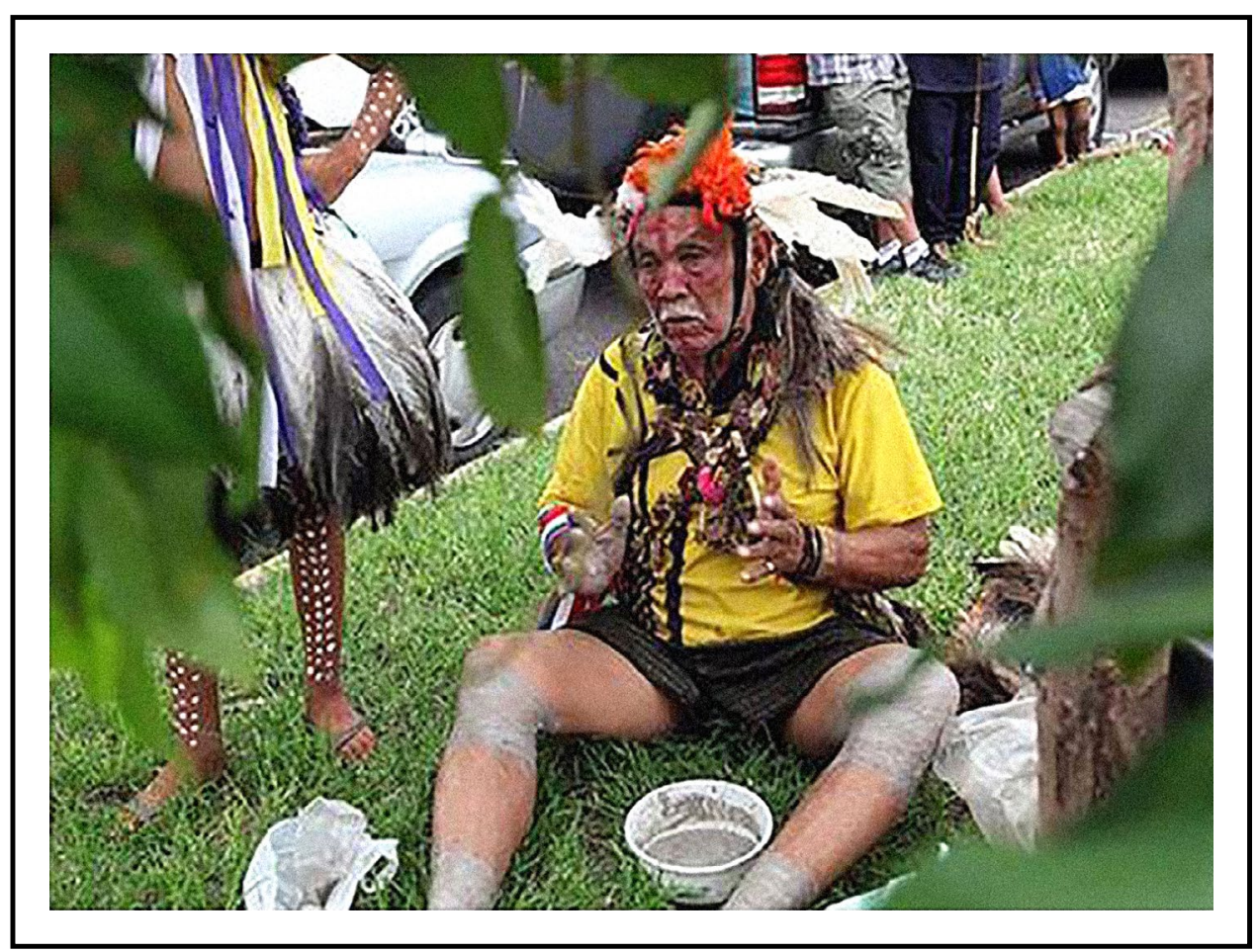

Figura 15. Clemente López preparándose para ceremonia ishir actual de reclamo territorial. Fuente: http://www.paraguay.com/nacionales/reclaman-su-tierra-sagrada-130150 
Estas manifestaciones artísticas expresan en algunas ocasiones el poder de los dioses, como en el caso de la caracterización de los anábsoro, seres divinos presentes en las ceremonias de iniciación de los jóvenes, o en otras instancias ceremoniales donde los konsaha se pintan y exhiben sus adornos plumarios, ya sea para ejercer el bien o la cura de los enfermos o para enviar maleficios, conjugan el uso del arte plumario con el de la pintura corporal (Escobar, 2012).

En este transitar de los rituales sagrados, se producen las combinaciones de los tres colores básicos impregnados sobre el cuerpo en un diálogo constante con los diferentes accesorios emplumados tales como el tocado cefálico, las muñequeras, las tobilleras, los cinturones, las diademas, los collares; absorbiendo los colores de su hábitat y así realzando los verdes, los azules, los amarillos, los marrones, los rosados, para concluir en los reflejos iridiscentes de las plumas del pato bragado. Mientras tanto, las fibras torsionadas y tejidas del caraguatá, a veces teñidas en colores marrones, azules y rojos, van enlazando y sujetando el material plumario, convirtiéndose así en el sostén principal de un material tan delicado como es la pluma.

\section{La resistencia emplumada de los pueblos originarios en Paraguay}

Los tomáraho constituyen actualmente una nación separada de los ebytoso, estos últimos siguen considerándose a sí mismos ishir o ishiro; ${ }^{18}$ mientras que los primeros decidieron separarse y formar un nuevo pueblo (A. Ozuna, com. pers., 2013).

Una forma actual de resistir, es decir, de enfrentarse a la realidad de despojo continuo del territorio y por consiguiente, del avasallamiento del espacio de vida del pueblo ishir, es denunciar a través de la implementación de ceremonias ancestrales pero resignificadas en un ámbito abierto como las que han

18 En 2013 tuvimos el gusto de conocer a Andrés Ozuna gracias al contacto de Adelina Pusineri del Museo Etnográfico Andrés Barbero de Asunción, Paraguay. En esa ocasión, Andrés nos brindó su conocimiento originario que nos ayudó a contextualizar el patrimonio ishir existente en nuestro museo. tenido lugar en Bahía Negra durante el transcurso del año 2015, cuyo objetivo es visibilizar las demandas territoriales para así poder alcanzar la seguridad jurídica de sus tierras (Figura 15). Y en este resistir, la indumentaria revestida de plumas cumple la doble función de exhibir el poder de las ceremonias ancestrales y mostrar al mundo entero, a través de las redes sociales y los medios de comunicación, que la identidad ishir está presente y lucha por seguir existiendo.

Otra forma de decir "acá estamos y queremos seguir viviendo como ishir, continuar manteniendo y transmitiendo la identidad cultural", es a través de la educación bilingüe y multicultural. La transcripción de los mitos en ishir y español a partir del trabajo de investigación de Andrés Ozuna, en la forma de un pequeño manual con dibujos del ishir Bruno Barras y con el objetivo de ser distribuido en las escuelas, permite no solo seguir conservando la memoria de este pueblo sino también contribuir al fortalecimiento de la lengua originaria. En este sentido Ozuna afirma que:

[...] es por eso que estas historias o mitos son muy importantes, por sus enseñanzas de hacer volver a nacer el fruto de nuestros ancestros, es como una flor que se marchitó en un desierto o es como hacer brillar la memoria de los grandes shamanes y ancianos de nuestra raza, pues para ellos es un gran honor hacer saber la importancia de los cuentos y mitos; que nuestros niños y niñas sepan el pensar y el sentir de los ishiro sobre una literatura que habla de su nación (Ozuna, s.f., p. 7).

\section{Un nuevo relato. Los ishiro como sujetos históricos frente al avance inconsulto}

El poder político de los shamanes transmutado en los últimos años se ha manifestado en diversos espacios, más allá de sus intervenciones como mediadores en cuestiones judiciales, de sanciones en su propia comunidad; las funciones de los shamanes se han ampliado hasta su participación en la resolución de conflictos con otros grupos étnicos e incluso con la sociedad "blanca" (Cordeu Ms., s.f.). 
En la actualidad, el avance de los sectores ganadero y sojero, de intereses privados es resistido por los ishiro frente a la indiferencia del gobierno de turno, que continúa sin atender los derechos constitucionales de los pueblos originarios en Paraguay. Reconocidos en su existencia anterior al Estado nacional, sin embargo éste no ofrece seguridad jurídica a los ishiro en relación a la posesión del territorio, permitiendo que empresas extranjeras continúen usurpando tierras originarias.

Uno de los roles de los shamanes actuales, como es el caso específico de Clemente López, ishir ebytoso de la comunidad de Karcha Balut, ${ }^{19}$ es el de la denuncia política por la usurpación del territorio. De esta forma, mediante la ejecución de rituales ceremoniales reclaman al Estado la devolución de 9500 ha ancestrales que hoy son propiedad privada. ${ }^{20}$ Ataviado con su vestimenta preparada para las ceremonias ancestrales, el shaman Clemente López exhibe sobre su cara pintada los diversos accesorios emplumados que dan prestigio y poder, en un nuevo entramado de su actuación política. Por otra parte, representantes ishiro iniciaron una serie de reuniones en la ciudad de Asunción con organismos del gobierno a fin de exigir la expropiación de las propiedades en manos de los terratenientes y la compra por parte del Estado paraguayo. ${ }^{21}$

19 Andrés Ozuna, nieto de Clemente López, nos contó que Karcha Balut puede traducirse como "caracol gigante" (A. Ozuna, com. pers., 2013).

20 Publicado el 19 de agosto de 2015 en http://www. ultimahora.com/indigenas-yshir-reclaman-ladevolucion-sus-tierras-ancestrales-el-chaco-n923080. html

21 Tras décadas de resistencia en la zona, los ishir enfrentan ahora una nueva amenaza: la del avance de las empresas ganaderas, en su mayoría de capital extranjero, que van estrechando el cerco en torno a sus tierras ancestrales. Las explotaciones ganaderas han invadido incluso un lugar considerado como sagrado para la cultura ishir, llamado eschma, que en la lengua de estos nativos significa "abundancia de peces". "Nuestros abuelos, que eran nómadas cazadores-recolectores, acostumbraban a ir a la laguna de la "abundancia de peces" para alimentarse, y durante mucho tiempo vivieron, trabajaron y comieron allá. Es un lugar sagrado e histórico para nosotros”, recordó Ozuna. Pero el territorio de eschma está hoy ocupado por la empresa ganadera Paraverde, propiedad de un empresario turco, que se encarga de autorizar o de bloquear el acceso de los indígenas a la finca. "Nosotros
En comunicados recientes distribuidos a través de las redes sociales y difundidos en algunos medios de comunicación, el pueblo ishir denuncia esta situación de despojo continuo y anuncia medidas concretas para la recuperación del territorio. Organizados en la UCINY (Unión de Comunidades Indígenas de la Nación Yshir), desde hace unos años vienen impulsando acciones políticas, administrativas y judiciales con el objetivo de lograr la restitución de las tierras y el cumplimiento de las demandas en educación, salud, medioambiente y el rescate de su cultura.

\section{Consideraciones finales}

El tocado de plumas existente en el Museo Etnográfico de la Universidad de Buenos Aires es parte de un complejo artístico, ceremonial y tecnológico del pueblo ishir del Chaco paraguayo. Nuestro "adorno de plumas" tal cual ha sido inventariado originalmente en 1912, es probable que haya sido usado por una persona con un rol específico en la sociedad ishir, el de shaman o konsaha, quien tenía atributos especiales y habría sido también el creador de este objeto singular.

no estamos acostumbrados a pedir permiso para transitar por las tierras, porque son nuestras tierras desde que vivían allí nuestros antepasados”, expuso el dirigente ishir. Además, denunció que ya se han producido algunos "roces y enfrentamientos" entre los indígenas y los peones de la estancia ganadera, dado que la explotación "corta la comunicación" entre varias de las comunidades del pueblo ishir. Por ello, representantes de los indígenas se desplazaron a Asunción para iniciar una ronda de contactos con autoridades estatales, entre ellas el Instituto Paraguayo del Indígena (INDI), y pedirles que estudien llegar a un acuerdo de compra o a una expropiación al propietario de Paraverde, y de este modo recuperen las tierras para los ishir. Solicitaron además que el Estado paraguayo acelere el proceso de transferencia de las tierras que son propiedad del INDI a los ishir, y les otorgue los correspondientes títulos de propiedad, a fin de que puedan defenderse como dueños legítimos de sus tierras frente al avance de las explotaciones agrícolas y ganaderas en la zona. El único antecedente durante la democracia de un caso en que el Estado paraguayo haya expropiado las tierras de una empresa privada para cederlas a una comunidad indígena, reconociendo que forman parte de su territorio ancestral es el de la comunidad Sawhoyamaxa, del pueblo énxet (publicado el 28 de junio de 2015 en http://www.elnuevoherald. com/noticias/mundo/america-latina/article25715470. html\#storylink=cpy). 
Enmarcado en una política institucional de acrecentamiento de las colecciones etnográficas dirigida por Juan B. Ambrosetti, este manahna hijá ingresó como parte de un conjunto más amplio de accesorios plumarios y otros objetos ishir donados por Victoria Aguirre en la primera década de 1900.

Antes de la Guerra del Chaco, durante las primeras tres décadas del siglo $\mathrm{XX}$, viajeros, fotógrafos y científicos naturalistas recorrieron el territorio ishir produciendo documentación fotográfica, registros de relatos míticos, información variada sobre quiénes eran los denominados chamacoco. Épocas además, de avance del Estado paraguayo y de intereses privados sobre las tierras productivas del pueblo originario.

Desde la mitad del siglo XX hasta nuestros días, el pueblo ishir recurrió a varias estrategias de resistencia y supervivencia con el objetivo de mantener viva su identidad cultural. Más allá de la implementación de nuevos métodos de subsistencia económica y frente a los cambios inevitablemente acaecidos en términos económicos, sociales y culturales; frente a la indiferencia del gobierno nacional que no contempla los derechos constitucionales de los pueblos originarios; el pueblo ishir continúa perpetuándose en su lengua nativa, en sus ritos de iniciación, en la figura de sus shamanes y en los usos de su vestimenta emplumada.

Es así como hoy podemos dar cuenta de la necesidad de comprender la historia de las colecciones en los museos y resignificar la cultura material que se encuentre en los mismos, a la luz de los reclamos indígenas y de la dinámica de los procesos identitarios. El uso continuo de este tipo de "objetos" nos habla de culturas vivas; imbuidas de poder sagrado en el pasado, hoy revisten también una fuerte carga simbólica y política, relacionada con los reclamos territoriales y los derechos a su identidad; todo lo cual nos obliga a analizar y discutir el papel del estudio de los objetos en los museos antropológicos actuales.

\section{Agradecimientos}

A nuestras y nuestros compañeroas de la reserva de etnografía del Museo por la buena disposición para que podamos estudiar el material: Alfonsina Elías, Mariana Abatizzi y Sebastián Cohen. A las compañeras de la Biblioteca Raúl Cortázar del Museo Etnográfico: Mónica Ferraro y Silvia Soruco. A Diego Olivera por enseñarnos a ver en las plumas a las aves. A Francine Schloeth y Valeria Dowding, por ayudarnos con algunas traducciones. Al profesor Edgardo Cordeu y a Ticio Escobar por su amabilidad y generosidad. A Andrés Ozuna y Clemente López, quienes por su corazonar y pensar nos han involucrado en el mundo ishir. A Ignacio Holder y Cecilia Lebrero por su disponibilidad. A nuestra querida amiga Verónica Jeria por su apoyo incondicional de siempre.

\section{Referencias citadas}

Baldus, H. (1927). Os indios chamacocos e a sua lingua. Revista do Museu Paulista, XV, 5- 68.

Belaieff, J. (1941). Los Indios del Chaco paraguayo y su tierra. Revista de la Sociedad Cientifica del Paraguay, V(3),1-48.

Boggiani, G. (1900). Compendio de etnografia paraguaya moderna. Asunción: H. Kraus.

Brooke, M. y Birkhead, T. (1991). The Cambridge Encyclopedia of Ornithology. Melbourne: Cambridge University Press.

CAV/Museo del Barro. (2008). Catálogo Museo de Arte Indigena. Asunción: Imp. Arte Nuevo.

Cordeu, E. (1980). Aishnuwérhta. Las ideas de deidad en la religiosidad chamacoco. Tesis doctoral. Facultad de Filosofía y Letras, Universidad de Buenos Aires, Buenos Aires.

Cordeu, E. (1986). Los atuendos shamánicos chamacocos del Museo Etnográfico. Un intento de interpretación simbólica. Runa, 16, 103-136. 
Cordeu, E. (1999). Transfiguraciones simbólicas. Ciclo ritual de los indios tomáraxo del Chaco Boreal. Quito: Abya Yala.

Cordeu, E. s.f. Ms. Desde la gerontocracia y los guerreros a los caciques@xxx.ong. La transformación de los esquemas políticos de los indios chamacoco en el contexto interétnico. En Tercer Simposio Chaco: Liderazgo, representatividad y control social en el Gran Chaco Sudamericano y zonas adyacentes. Resistencia, 17-18 de agosto de 2006.

DGEEC. (2004). Atlas de las comunidades indigenas en el Paraguay. Asunción: Dirección General de Estadística, Encuestas y Censos.

Di Lorenzo, S., Manuale, S. y Olivera, D. (2015). El pueblo ishir y las plumas sagradas del Chaco paraguayo. Una mirada a las colecciones del Museo Etnográfico "Juan B. Ambrosetti" de la Universidad de Buenos Aires. Actas de la XXIX RAE: "La rebelión de los objetos. Arte plumario" (pp. 223-250). La Paz.

Escobar, T. (1999). La maldición de Nemur. Acerca del arte, el mito y el ritual de los indigenas ishir del Gran Chaco paraguayo. Asunción: Centro de Artes Visuales/Museo del Barro.

Escobar, T. (2012). La belleza de los otros. Arte indigena del Paraguay. Asunción: Servilibro.

Kandert, J. (1983). Alberto Vojtech Frîc. On the centenary of his birth. Annals of the Náprstek Museum, 11, 111-146.

Krieg, H. (1934). Chaco Indianer. Ein Bilderatlas. Stuttgart: Strecker und Scröder Verlag.

Marcos, S. I. (1999). Relatos de El Viejo Antonio. México D.F.: EON.

Narosky, T. e Yzurieta, D. (2006). Guia para la identificación de las aves del Paraguay. Vázquez Mazzini (Ed.). Buenos Aires: Guyrá.
Ozuna, A. s.f. Historias de la nación yshir ybytoso. Asunción: Ministerio de Educación y Cultura, AGR Servicios Gráficos.

Pegoraro, A. (2009). Las colecciones del Museo Etnográfico de la Universidad de Buenos Aires: un episodio en la historia del americanismo en la Argentina: 1890- 1927. Tesis doctoral. Facultad de Filosofía y Letras, Universidad de Buenos Aires, Buenos Aires.

Reyero, A. (2012). Imagen, objeto y arte: la fotografía de Guido Boggiani. Iconos. Revista de Ciencias Sociales. Consultado 12.12.2015.

Ribeiro, B. (1957). Bases para uma classificação dos adornos plumarios dos indios do Brasil. Separata de Arquivos do Museu Nacional, XLIII, 59 -116.

Ribeiro, B. (1988). Dicionário do artesanato indígena. São Paulo: Editorial da Universidade de São Paulo.

Richard, N. (2008). Les chiens, les hommes et les étrangers furieux. Archéologie des identités indiennes dans le Chaco Boréal. Tesis doctoral. París: École des Hautes Études en Sciences Sociales.

Seiler Baldinger, A. (1994). Textiles. A classification of techniques. Washington D.C.: Smithsonian Institute Press.

Sequera, G. (2006). Tomárâho, La resistencia anticipada. Tomo 1 CEADUC. Asunción: Imprenta Salesiana.

Spadafora, A. M. (2006). Entre la historia, el mito y el ritual: notas sobre el arte chamacoco (Alto Paraguay). Boletín de Antropología, 20(37), 118-130.

Susnik, B. (1957). Estudios chamacoco. Boletín de la Sociedad Científica del Paraguay y del Museum Dr. Andrés Barbero (I), Etnografía, I, 1-153.

Trevisan, E. (1980). Vultos tchecos no Brasil e no Paraná. A contribução humánitaria de Albert Vojtech Frîc. Boletim do Instituto Histórico, Geográfico e Etnográfico Paranaense, XXXVII, 14-55. 
